\title{
Cystoderma, Cystodermella and Ripartitella in Atlantic Forest, São Paulo State, Brazil
}

\author{
Marina Capelari ${ }^{1,2}$ and Tatiane Asai ${ }^{1}$
}

Received: 29.01.2009; accepted: 28.05.2009

\begin{abstract}
Cystoderma, Cystodermella and Ripartitella in Atlantic Forest, São Paulo State, Brazil). This paper reports on the genera Cystoderma, Cystodermella and Ripartitella from Atlantic Rainforest, Southeast Brazil. They are represented by Cystoderma chocoanum, Cystodermella contusifolia, C. sipariana and Ripartitella brasiliensis. Cystoderma chocoanum is reported for the first time outside the type locality (Colombia) and its relationship with others species of Cystoderma, based on nLSU rDNA sequences, is discussed.
\end{abstract}

Key words: Basidiomycota, diversity, molecular analysis, taxonomy

RESUMO - (Cystoderma, Cystodermella e Ripartitella em Mata Atlântica, São Paulo, Brasil). Este trabalho reporta a ocorrência dos gêneros Cystoderma, Cystodermella e Ripartitella para Mata Atlântica, São Paulo, Brasil. Foram registrados Cystoderma chocoanum, Cystodermella contusifolia, C. sipariana e Ripartitella brasiliensis. Cystoderma chocoanum é registrada pela primeira vez fora da localidade tipo (Colômbia) e sua relação com outras espécies de Cystoderma, baseadas em seqüências de nLSU DNAr, é discutida.

Palavras-chave: análise molecular, Basidiomycota, diversidade, taxonomia

\section{Introduction}

The species from genus Cystoderma Fayod was separated in two distinct genera, Cystoderma s. str. and Cystodermella by Harmaja (2002), considering the amyloidity of basidiospores; previously unused differences or tendencies present in the genus, like 'harpoon' cystidia, arthrospores in fruit body and/or mycelium culture, liability to Squamanita, bryophily; nuclear DNA content, and the results of phylogenetic analysis. The phylogenetic analysis clusters Cystodermella close to Ripartitella Singer and Cystoderma to Floccularia Pouzar [F. albolanaripes (G.F. Atk.) Redhead].

Ripartitella was erected by Singer (Singer 1947) as a monotypic genus close to Cystoderma with the species $R$. squamosidisca (Murrill) Singer. According to Singer (1946) the two genera differ in three important characteristics: the covering layer structure of pileus and stipe, which is an epithelium in Cystoderma and a trichodermium in Ripartitella; the spore wall, always smooth in Cystoderma and echinulate in Ripartitella, and the eccentric position of the stipe in a large number of basidioma of Ripartitella, whereas Cystoderma is centrally stipitate. Singer (1949) considered only one species in the genus, reducing $R$. squamosidisca to synonym of $R$. brasiliensis (Speg.) Singer. The late species was based on Pleurotus brasiliensis Speg. collected in Apiaí, São Paulo State, by Puiggari (Spegazzini 1889). Later, R. sipariana (Dennis) Dennis (Dennis 1970), R. ponderosa (A.H. Sm. \& Singer) Franco-Mol. (Franco-Molano 1993) and R. alba Halling \& FrancoMol. (Halling \& Franco-Molano 1996) were added to the genus. Of these species, $R$. sipariana has smooth basidiospores, which exclude it from Ripartitella and is better classified under Cystodermella, since the basidiospores are also inamyloid. Halling \& Franco-Molano (1996) demonstrated that Cystoderma ponderosa A.H. Sm. \& Singer has ornamented spores and no sphaerocytes at the pileipellis.

Singer (1986) classified Cystoderma and Ripartitella in tribus Cystodermateae family Agaricaceae. However other authors as Thoen (1969), Heinemann \& Thoen (1973) and Harmaja (1979) considered Cystoderma in Tricholomataceae without mention on Ripartitella while Pegler (1983) considered Cystoderma in Agaricaceae following Singer (1986) and Ripartitella in Tricholomataceae. The first published paper with molecular data (Johnson

1. Instituto de Botânica, Seção de Micologia e Liquenologia, Caixa Postal 3005, 01061-970 São Paulo, SP, Brazil

2. Corresponding author: mcapelariibot@yahoo.com 
\& Vilgalys 1998) suggested the exclusion of tribus Cystodermateae from the family Agaricaceae, which was followed by Kirk et al. (2001). In further studies (Moncalvo et al. 2002) Ripartitella and Cystoderma (including C.granulosum transferred to Cystodermella) remained outside the clade Agaricaceae and the family Tricholomataceae was split in several clades without the presence of Ripartitella, Cystoderma and Cystodermella. The last edition of the "Dictionary of the Fungi" (Kirk et al. 2008) considers the three genera in Agaricaceae with the observation that studies with more species of these genera are required before they can be addressed to a definitive family.

The three genera occur in São Paulo State, with Cystoderma amianthinum (Bononi et al. 1981, Capelari 1989, Pegler 1997); Cystodermella contusifolia (Pegler) Harmaja (Capelari 1989, Pegler 1997, as Cystoderma contusifolium), C. sipariana (Pegler) Harmaja (Pegler 1997, as Cystoderma siparianum) and Ripartitella brasiliensis (Spegazzini 1889, Grandi et al. 1984, Pegler 1997). Recently Wartchow et al. (2007) cited $R$. alba and $R$. brasiliensis from Pernambuco State.

In this paper the specimens belonging to these genera from Herbarium SP were revised, including a recent collection of a Cystoderma species that resembles $C$. amianthinum. The molecular analysis of the nLSU gene was also made, with the aim of ordering the Brazilian species and its relationship with C. amianthinum, a species essentially from temperate, not tropical region (Heinemann \& Thoen 1973).

\section{Material and methods}

Sampling - The studied material was collected at Parque Estadual das Fontes do Ipiranga (PEFI), a forest reserve in the south of São Paulo City (2339'S and $\left.46^{\circ} 37^{\prime} \mathrm{W}\right)$, Reserva Biológica de Paranapiacaba

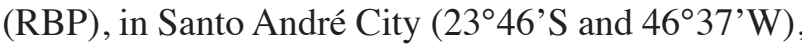
both remainings of Atlantic Rainforest in urban area, and Parque Estadual da Ilha do Cardoso, in the south of São Paulo State $\left(25^{\circ} 10^{\prime} \mathrm{S}\right.$ and $\left.48^{\circ} \mathrm{W}\right)$, a preserved Rainforest.

Morphological study - The microscopic analysis was made from dried material rehydrated in $70 \%$ ethanol, followed by $5 \% \mathrm{KOH}$ and Melzer's reagent. The $\mathrm{Q}_{\mathrm{m}}$ represents the mean length/width quotient of the total spores measured. The colours of fresh material were compared with Küppers (1979) and specimens are deposited at Herbário do Estado Maria Eneyda P. Kauffmann Fidalgo (SP).
Molecular study - The nLSU rDNA sequences were used for phylogenetic analysis, in order to elucidate the relationship of $C$. chocoanum found in São Paulo, Brazil with sequences deposited in the GenBank (table 1).

DNA extraction - Procedures for DNA extraction were according to an adapted protocol of Ferreira \& Grattapaglia (1995) using lyophilized basidiomata previously grounded to a fine powder in liquid nitrogen. The sample was resuspended in $50 \mu \mathrm{L}$ of TE, incubated at $37{ }^{\circ} \mathrm{C}$ for $30 \mathrm{~min}$ after the addition

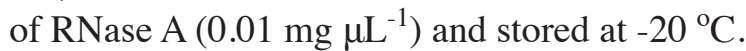
PCR amplification and DNA sequencing - The 5' end of the nLSU rDNA was targeted for amplification. The nLSU region was amplified using the primer set LR16 and LR0R (Moncalvo et al. 2000). PCR reaction, containing $0.5 \mathrm{U}$ of Platinum ${ }^{\circledR}$ Taq DNA Polymerase - Brazil (Invitrogen, São Paulo City, SP, Brazil), $0.2 \mathrm{mM}$ of each dNTP, $1 \mathrm{mM}$ of $\mathrm{MgCl}_{2}$, $1 \%$ of polyvinylpyrrolidone (Sigma, St. Louis City, $\mathrm{MO}, \mathrm{USA}$ ) and $0.1 \mu \mathrm{M}$ of each primer of the selected region in $50 \mu \mathrm{L}$, was performed in a Progene (Techne, Staffordshire, UK) thermocycler. The program was initiated by a 5 -min denaturation step at $92^{\circ} \mathrm{C}$, followed by 40 cycles of $40 \mathrm{sec}$ at $92^{\circ} \mathrm{C}, 90 \mathrm{sec}$ at $40{ }^{\circ} \mathrm{C}$ and 2 min at $72{ }^{\circ} \mathrm{C}$. The polymerization was completed by a 5 -min incubation at $72{ }^{\circ} \mathrm{C}$. Amplification products were electrophoresed in a $1.5 \%$ agarose gel containing $0.1 \mu \mathrm{g} \mathrm{mL}^{-1}$ ethidium bromide. PCR products were then purified using PureLink PCR Purification Kit (Invitrogen, São Paulo City, SP, Brazil).

DNA sequencing reactions were performed with the Applied Biosystems (ABI) BigDye Terminator Cycle Sequencing Kit v.3.1. in an ABI Prism 377 automated DNA sequencer (Applied Biosystems, Foster City, CA, USA) according to the manufacturer's instruction. The sample was sequenced in both directions with the same primers. The sequence was deposited in the GenBank.

Data analysis - Initially, a blast search was conducted in the GenBank to compare the sequence of $C$. chocoanum with the existing sequence data. Phylogenetic analysis was done using nLSU sequence determined in this study with nine sequences available in the GenBank (table 1).

The sequences were analyzed using BioEdit version 7.0.5.3 (Hall 1999) and then automatically aligned in Clustal W (Thompson et al. 1994). The alignment was deposited in the TreeBase. Parsimony analysis was performed with PAUP version $4.0 \mathrm{~b} 10$ (Swofford 2001). Most parsimonious tree was 
Table 1. Collection data and GenBank accession number of the taxa analyzed.

\begin{tabular}{|c|c|c|c|c|}
\hline Species & Culture/herbarium $\mathrm{n}^{\circ}$ & Locality & GenBank n ${ }^{\circ}$ & Reference \\
\hline \multirow{5}{*}{$\begin{array}{l}\text { Cystoderma } \\
\text { amianthinum }\end{array}$} & TUB 011551 & & DQ071703 & Garnica et al. 2007 \\
\hline & JFA 12566 & Sweden & DQ154108 & GenBank \\
\hline & GLM 45916 & Germany & AY207195 & Walther et al. 2005 \\
\hline & DAOM 188121 & & AF261473 & Moncalvo et al. 2002 \\
\hline & GG_BM05B & $\begin{array}{l}\text { United } \\
\text { Kingdom }\end{array}$ & EF535265 & $\begin{array}{l}\text { Matheny et al. } \\
\text { not published }\end{array}$ \\
\hline \multirow[t]{2}{*}{ C. chocoanum } & NY-EFM629 & Colombia & U85302 & Johnson \& Vilgalys 1998 \\
\hline & SP393641 & Brazil & EU727143 & this paper \\
\hline C. granulosum & BPI 752511 & United States & U85299 & Johnson \& Vilgalys 1998 \\
\hline C.jasonis & GLM 45917 & Germany & AY207196 & Walther et al. 2005 \\
\hline $\begin{array}{l}\text { Ripartitella } \\
\text { brasiliensis }\end{array}$ & NY-EFM 744 & Colombia & U85300 & Johnson \& Vilgalys 1998 \\
\hline Lepiota cristata & $\mathrm{DA}-45^{\mathrm{a}}$ & Germany & AF391071 & Vellinga 2001 \\
\hline
\end{tabular}

obtained by heuristic searches with simple sequence addition in 1,000 replicates, employing tree-bisectionreconnection (TBR) branch-swapping algorithm. Characters from the extreme $5{ }^{\prime}$ and $3^{\prime}$ ends of the sequences were deleted from all taxa to obtain individual datasets that had identical start and end positions, gaps were treated as missing, all characters were unordered and equally weighted, multistate taxa interpreted as uncertainty, starting trees obtained via stepwise addition, one tree held at each step during stepwise addition, steepest descent option not in effect, initial MaxTrees was set to auto-increase, branches of zero length were collapsed (creating politomies), and MulTrees options in effect.

Branch and branch node supports were determined using 1,000 bootstrap replicates. Estimated levels of homoplasy and phylogenetic signal (retention and consistency indexes) were determined. Trees generated were rooted to Lepiota cristata Barla as the outgroup taxa.

\section{Results and Discussion}

Molecular analysis - Ten taxa plus the outgroup Lepiota cristata were aligned. The alignment dataset consisted of 1,480 characters, including gaps. Prior to analysis, 859 characters from 5' and 3' ends of the sequences were excluded. Out of the 621 characters included in the analysis, 279 characters were constant, 307 variable characters were parsimony-uninformative and 35 were parsimony informative.

The heuristic searches with 1,000 bootstrap replicates resulted in one most parsimonious tree, with the following scores: tree length $=374$ steps, consistency index $=0.968$, retention index $=0.806$, rescaled consistency index $=0.781$, homoplasy index $=0.032$.

The parsimony tree generated from nLSU sequence data using species of Cystoderma and Ripartitella revealed two major clades (figure 1). The upper clade, clustered $C$. granulosum and $R$. brasiliensis with $83 \%$ of bootstrap support. This was demonstrated before by Moncalvo et al. (2002) and utilized by Harmaja (2002) to create the genus Cystodermella segregated from Cystoderma. Meanwhile, all other species of Cystoderma appears in the lower clade separated into two groups with 77\% of bootstrap support. Cystoderma chocoanum from Brazil appears in the first group with $C$. chocoanum from Colombia, in a clade with $100 \%$ of bootstrap support. It shows that the Brazilian species belongs to C. chocoanum, also confirmed by the morphological analysis. C. jasonis and C. amianthinum clustered in the second group.

In the analysis of Moncalvo et al. (2002), Floccularia albolanaripes (G.F. Atk.) Redhead (GenBank AF261380) appears as a sister group of Cystoderma with a low bootstrap support $(<50 \%)$. They presented no explanation for this fact because there are no obvious morphological relations between the two genera. This sequence appeared in the blast search made with the sequence of $C$. chocoanum obtained for this study, and, when added to the dataset analyzed, F. albolanaripes appears in the Cystoderma clade with a bootstrap support of 58\% (data not shown). 


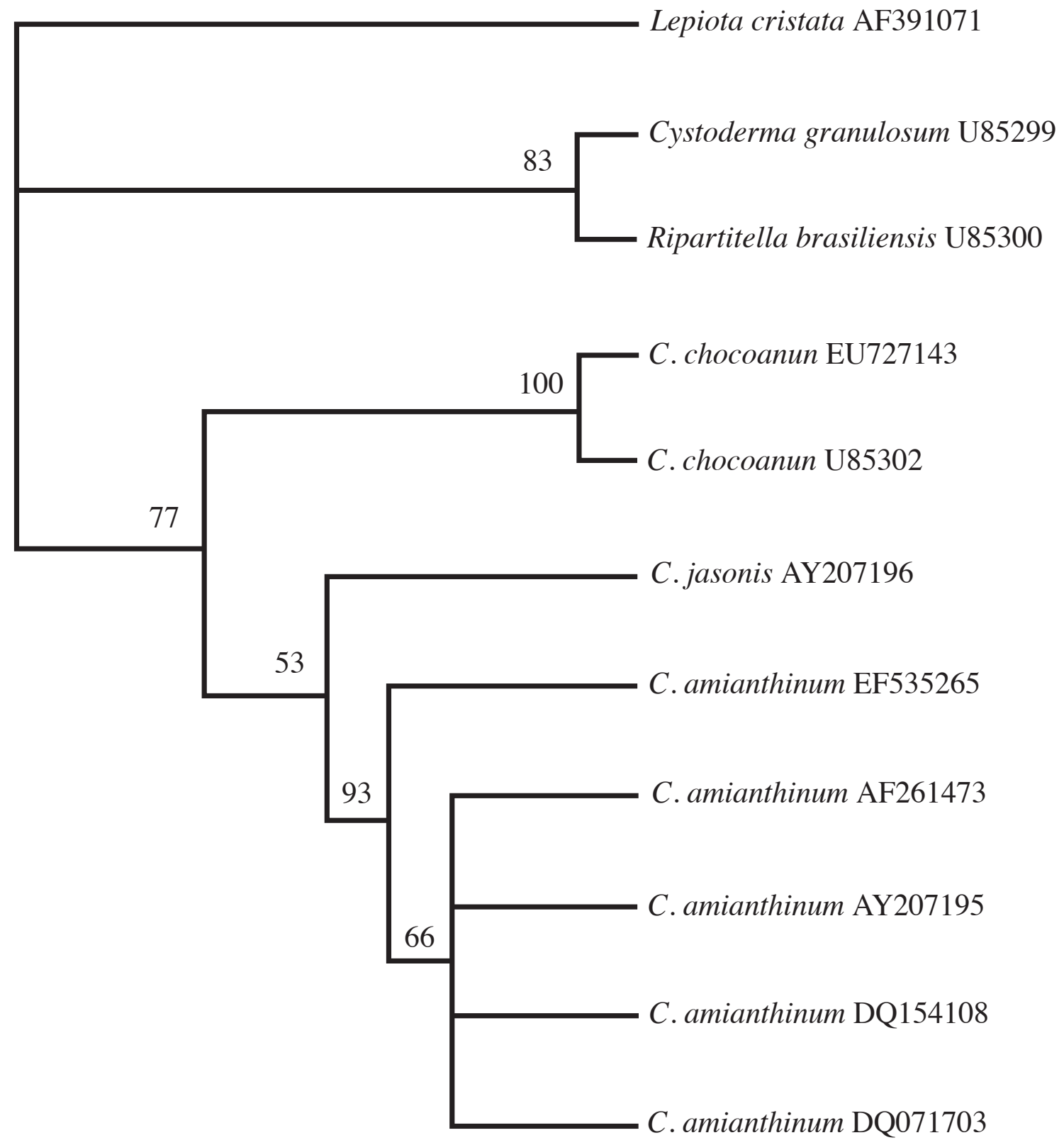

Figure 1. Cladogram generated by parsimony analysis of partial LSU rDNA sequences. Bootstrap values $\geq 50 \%$ are shown above branches. GenBank accession numbers are shown after each taxon name. 
Floccularia Pouzar (Pouzar 1957) was placed in Amanitaceae mainly because of the bilateral lamellar trama and amyloid basidiospores. It comprises six species distributed in the United States and Europe, and $F$.albolanaripes is the only species with sequence in the GenBank. This species, according to Mitchel \& Smith (1976, as Armillaria albolanaripes G.F. Atk.) does not have divergent hyphae in lamellar trama, has weakly amyloid basidiospores and do not have any kind of sphaerocytes at the pileipellis.

In another molecular analysis where Cystoderma species were included (Johnson \& Vilgalys 1998, Walther et al.2005, Matheny et al.2006), Floccularia was not considered. For a better resolution of Cystoderma and Cystodermella containing clade, a larger sampling including other North American and European species of Floccularia is necessary, since the introduction of $F$. albolanaripes changes the relations among the two genera, and because they are morphologically very distinct.

Taxonomy - This key presents only the species studied. Identification keys for other species can be found in Smith \& Singer (1945), Thoen (1969), Heinemann \& Thoen (1973) and Saar (2003).

1. Basidiospores echinulate, pileipellis a trichodermium Ripartitella brasiliensis

1. Basidiospores smooth, pileipellis an epithelium with sphaerocytes

2. Pileus orange-brown to goldenbrown, basidiospores amyloid ...

Cystoderma chocoanum

2. Pileus whitish, basidiospores inamyloid

3. Pleurocystidia absent Cystodermella contusifolia

3. Pleurocystidia present Cystodermella sipariana

Cystoderma chocoanum Franco-Mol., Mycologia 85: 673. 1993.

Figure 2 a-d

Pileus (8-)20-40 mm diam., convex to applanate, surface dry, orange-brown $\left(\mathrm{N}_{40} \mathrm{~A}_{70} \mathrm{M}_{50}\right)$ to goldenbrown, with a darker centre $\left(\mathrm{N}_{60} \mathrm{~A}_{99} \mathrm{M}_{60}\right)$, covered by small squamules, that leaves a pruinose aspect to the pileus, membranous, not hygrophanous, margin appendiculate, involute when young, applanate to revolute when well developed. Lamellae adnexed, subdecurrent to slightly decurrent, white to whitish, crowded, with lamellulae of four lengths, margin entire. Stipe $25-55 \times<1-5 \mathrm{~mm}$, cylindrical, slightly subbulbous at the base, sometimes flexuous or napiform, tough, white to yellowish at the apex, above the annulus, deep brown to blackish towards the base, under the annulus, covered by a layer of whitish tissue similar to the tissue forming the annulus, solid. Annulus flaring, superior, whitish, as a result of the sheet that recovers the stipe. White basal mycelium at the base. Context white, very thin. Spore print white to beige with some brownish spots. Basidiospores (5-)6-7.2 $\times$ (2.5-)3.7-4 $\mu \mathrm{m},\left(\mathrm{Q}_{\mathrm{m}}=1.7\right)$, ellipsoid, smooth, thinwalled, hyaline, strongly amyloid, without germ pore. Basidia 21.2-22.5 $\times 7 \mu \mathrm{m}$, clavate, hyaline, thin-walled, with four sterigmata, with internal content. Basidioles present, similar to basidia. Pleurocystidia absent. Cheilocystidia absent, lamellae margin fertil. Context hyaline, thin, formed of hyaline, thin-walled, septated hyphae, with clamp-connexions, 3.5-7.5 $\mu \mathrm{m}$ diam., less condensed near the pileipellis. Hymenophoral trama regular, hyaline, of thin-walled, hyaline, septated hyphae, with clamp-connexions, 3.7-11.2 $\mu \mathrm{m}$ diam., some slightly inflated. Pileipellis composed of chains of brownish sphaerocytes, globose, some with a small papillae, 27.5-40 $\mu \mathrm{m}$ diam., with thin to thick wall, vacuolar content, without evident reddening in $\mathrm{KOH}$. Annulus tissue composed by hyaline hyphae, 5-7.5 $\mu \mathrm{m}$ diam., branched and interwoven, slightly thick-walled, septated, with clamp-connexions, ending in a chain of globose cells, hyaline to brownishpigmented, with minute clamp-connexions, terminal elements 18.7-38.7 × 13.7-20 $\mu \mathrm{m}$.

Habitat: Gregarious to caespitose on decaying wood.

Known distribution: Brazil (Bononi et al. 1981, Capelari 1989, Pegler 1997), Colombia (FrancoMolano 1993).

Material examined: BRAZIL. São PAULo: Cananéia, Parque Estadual da Ilha do Cardoso, hillside of Morro dos Três Irmãos, 28-VIII-1984, M. Capelari 157 (SP); idem, left side of Santa Cruz River, 30-I-1985, M. Capelari 267 (SP); idem, Morro das Almas, 30-X1985, M. Capelari et al.s.n.(SP194003); Santo André, Reserva Biológica de Paranapiacaba, 1-IV-1992, L.K. Okino et al. 306 (SP); idem, trail n. 2, 20-IV-2006, F. Karstedt \& M. Capelari 620 (SP).

Additional material examined: BRAZIL. RondôNIA: Jaru, $9^{\circ} 15^{\prime} \mathrm{S}-61^{\circ} 40^{\prime} \mathrm{W}, 15-\mathrm{X}-1986, M$. Capelari \& R. Maziero 1164 (SP). 
344 Hoehnea 36(2): 339-348, 1 tab., 3 fig., 2009

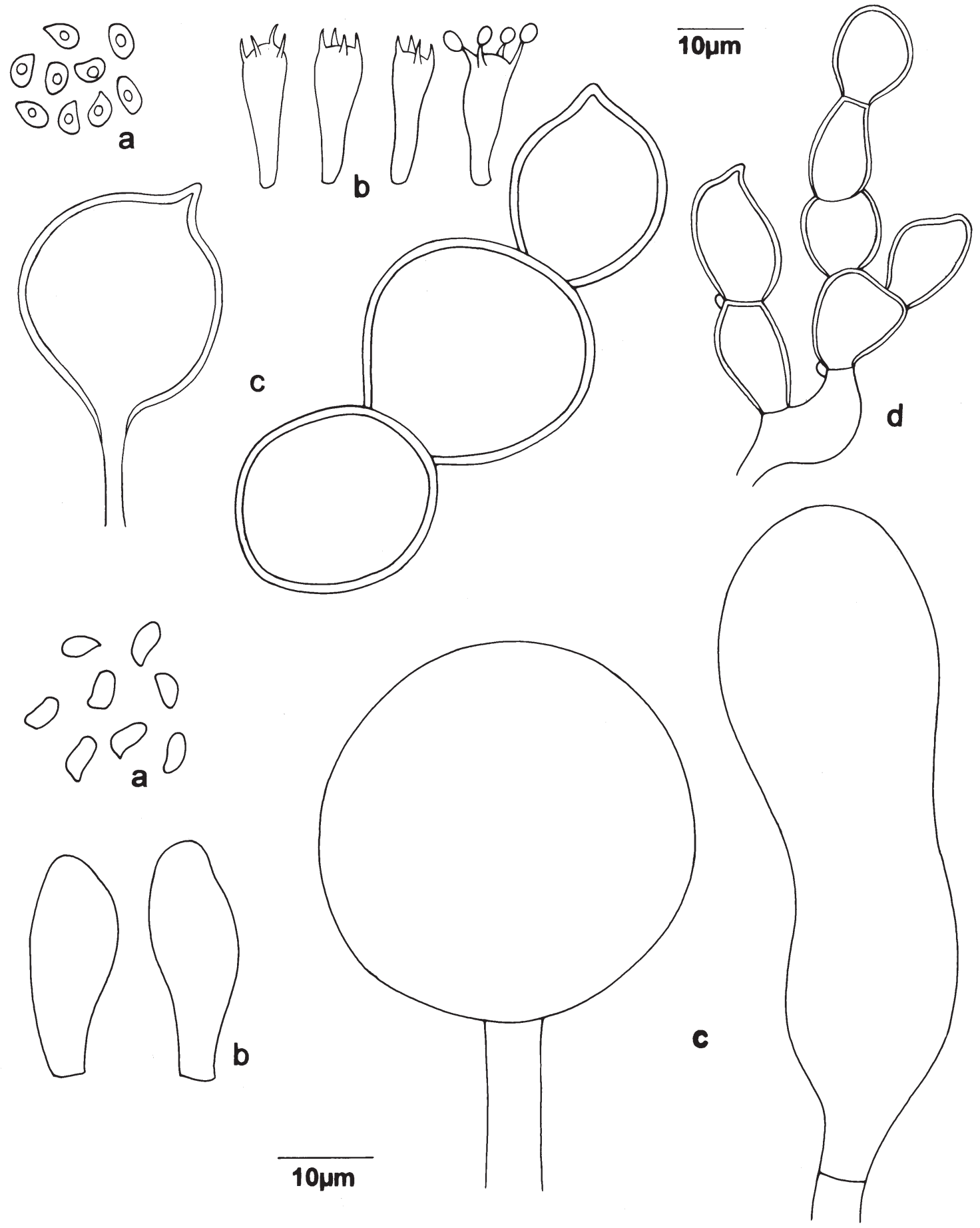

Figure 2. a-d. Cystoderma chocoanum. a. Basidiospores. b. Basidia. c. Elements of pilear surface. d. Elements of the annulus. e-g. Cystodermella contusifolia. e. Basidiospores. f. Cheilocystidia. g. Elements of pilear surface. 
Little morphological differences were observed between the Brazilian material and the original description for the Colombian material (FrancoMolano 1993). Macroscopically the pileus surface of the Brazilian collections is not areolate and the lamellae attachment is more decurrent than mentioned by Franco-Molano (1993). The basidiospores have comparable dimensions, but the pear-to-kidney shape mentioned was not observed in the Brazilian collections, all samples were ellipsoid. The others characteristics are in accordance.

Cystoderma chocoanum was previously registered from Brazil as $C$. amianthinum by Bononi et al. (1981), Capelari (1989) and Pegler (1997). The citations of $C$. amianthinum made by Singer (1969) for Argentine, Chile and Bolivia, and by Dennis (1961) for Venezuela, probably also represent $C$. chocoanum or another species, since, at least once, Singer (1969) said that the South American collections are close to the typical $C$. amianthinum, with differences at pileus surface and basidiospores.

Cystoderma austrofallax Smith \& Singer, described from Chile is also close to $C$. chocoanum, differing in the pileus colour and small basidiospores (3.5-5 $\times 3$ $\mu \mathrm{m})$, strongly amyloid reaching a violaceous colour and a strong reaction of the pilear surface to intense ferruginous-orange with KOH (Singer 1969).

Molecular analysis with the North and South American species of Cystoderma will be necessary to show the relations between $C$. fallax, already mentioned by Franco-Molano (1993) as close to $C$. chocoanum, C. austrofallax and the others South American species, in order to confirm the presence of $C$. amianthinum in South America.

Cystodermella contusifolia (Pegler) Harmaja, Karstenia 42: 46.2002 ECystoderma contusifolium Pegler, Kew Bull. add. ser. 9: 410. 1983.

Figure 2 e-g

Pileus $20-40 \mathrm{~mm}$ diam, conic to campanulate, expanding, surface whitish, covered with verrucose to pyramidal brownish squamules especially at the disk, non-striate, not hygrophanous, margin smooth. Lamellae adnexed, whitish, crowded, with lamellulae of two lengths, margin entire. Stipe $20-55 \times 2-4 \mathrm{~mm}$, cylindric, uniform, solid, whitish, surface pruinose to weakly squamulose, squamules concolorous. Annulus absent. Context white, thin. Spore print not seen. Basidiospores $3.6 \times 2.4 \mu \mathrm{m}\left(\mathrm{Q}_{\mathrm{m}}=1.5\right)$, ellipsoid, smooth, thin-walled, hyaline, inamyloid, without germ pore. Basidia not observed. Pleurocystidia absent. Cheilocystidia 19.2-21.6×7.2 $\mu \mathrm{m}$, ventricose, thin-walled, hyaline. Context hyaline, thin, formed of hyaline, thin-walled septated hyphae, with clampconnexions, 3.6-8.4 $\mu \mathrm{m}$ diam. Hymenophoral trama regular, hyaline, of thin-walled septated hyphae, with clamp-connexions, 8.4-9.6 $\mu \mathrm{m}$ diam. Pileipellis an epithelium of detersile sphaerocytes 36-60 $\mu \mathrm{m}$ diam., subglobose to globose, with brownish wall and palebrownish vacuolar content.

Habitat: on soil.

Known distribution: Brazil (Capelari 1989), Martinique (Pegler 1983).

Material examined: BRAZIL. São PAUlo: Cananéia, Parque Estadual da Ilha do Cardoso, trail to Morro das Almas, 30-X-1985, M. Capelari 450 (SP).

This species was described based on material collected in Martinique. The Brazilian material agrees with the original description, except for pileus colour, that is very pale ochraceous, and the slightly bigger cheilocystidia $(18-38 \times 4-10 \mu \mathrm{m})$ mentioned by Pegler (1983). The identification of the Brazilian material was confirmed by Dr. Pegler and, as far as we know, it is represented only by the type and this collection.

Cystodermella sipariana (Dennis) Harmaja, Karstenia 42: 46. 2002 三 Lepiota sipariana Dennis, Kew Bull. 7: 488. 1953 = Cystoderma siparianum (Dennis) Thoen, Bull. Jard. Bot. Nat. belg. 39: 190. 1969 = Ripartitella sipariana (Dennis) Dennis, Kew Bull. Addit. Ser. 3: 58. 1970.

Description: See Pegler (1983).

Habitat: on soil of "restinga" vegetation.

Known distribution: Brazil (Pegler 1997), Trinidad (Dennis 1953, 1970).

Material examined: BRAZIL. São PAUlo: Cananéia, Parque Estadual da Ilha do Cardoso, Restinga do Pereirinha, 9-I-1990, M. Capelari et al. 3010 (SP).

Pegler (1983) presents a description of this species and the only material that could be assigned to it, present at Herbarium SP, is completely contaminated by molds. Few observations were recovered. The pileipellis has sphaerocytes peculiar to Cystodermella, and basidiospores are smooth and inamyloid.

Pegler (1997) cited four Brazilian materials under this species. From them, SP193723, also from Parque 
Estadual da Ilha do Cardoso is Lepiota abruptibulba Murrill (Capelari 1989) as mentioned under this late species (Pegler 1997, p. 38). The two materials from Parque Estadual de Campos do Jordão were not found at Herbarium SP and the last (Capelari et al. 3010) is very moldy. Until now the species has not been found again.

Ripartitella brasiliensis (Speg.) Singer, Lilloa 22: 452. $1951 \equiv$ Pleurotus brasiliensis Speg., Bull. Acad. Nac. Cienc. Cordoba, 11: 398. 1889.

= Marasmius squamosidiscus Murrill,Bull. Torrey Bot. Club 67: 151.1940 झ Ripartitella squamosidisca (Murrill) Singer, Mycologia 39: 85. 1947.

= Lentodium floridanum Murrill, Mycologia 35: 426. 1943.

= Collybia pseudoboryana Dennis, Trans. Brit. Mycol. Soc. 34: 453. 1951.

$=$ Lepiota armillarioides Dennis, Kew Bull. 7: 486. 1952.

Figure 3

Pileus 14-35 mm diam., applanate to somewhat depressed at the centre, white with brown to reddish brown squamules, dense in the centre and diminishing towards the margin; when young the squamules cover all the surface, fleshy, not hygrophanous, margin ondulate, sometimes revolute, appendiculate. Lamellae adnexed to sinuated, white, crowded, with lamellulae. Stipe
$16-50 \times 1.7-3 \mathrm{~mm}$, central, sometimes tapered towards the base, apex somewhat flattened, white at the apex, above the annulus, beige under annulus, fibrillose to squamulose, squamules whitish to brownish. Annulus evanescent, white. Spore print white. Context white, thin. Basidiospores minute, 3.7-4 × $3 \mu \mathrm{m}\left(\mathrm{Q}_{\mathrm{m}}=1.3\right)$, subglobose, echinulate, hyaline, thin-walled, inamyloid. Basidia 25-27.5 × 6.2-7.5 $\mu \mathrm{m}$, clavate, hyaline, thinwalled, with four proeminent sterigma, clamp-connexions present at the base. Pleurocystidia sometimes abundant, 37.5-50 × 2.5-6.2(-8.7) $u \mathrm{~m}$, cylindrical to lageniform, hyaline, thin-walled, with incrustations dissolving in $\mathrm{KOH}$. Cheilocystidia absent. Context hyaline, thin, formed of hyaline, thin-walled, septated, sometimes inflated hyphae, sometimes branched, interwoven, with minute clamp-connexions 3.7-7.5(-18.7) $\mu \mathrm{m}$ diam. Hymenophoral trama irregular, hyaline, of thin-walled, hyaline, septated hyphae, with minute clamp-connexions, 6.2-8.7 $\mu \mathrm{m}$ diam. Subhymenium slightly dextrinoid. Pileipellis a trichodermium, sometimes with globose detersile elements, brownish, 22.5-25 um diam., from the pilear squamules.

Habitat: gregarious to caespitose, on soil.

Known distribution: Bolivia, Bonin Islands (Ovrebo 1988), Brazil (Spegazzini 1889, Grandi et al. 1984, Pegler 1990, 1997, Meijer 2001), Colombia (Ovrebo 1988), Kenya (Pegler 1977), Martinique (Ovrebo 1988), Mexico (Guzmán-Dávalos \& Guzmán 1988),
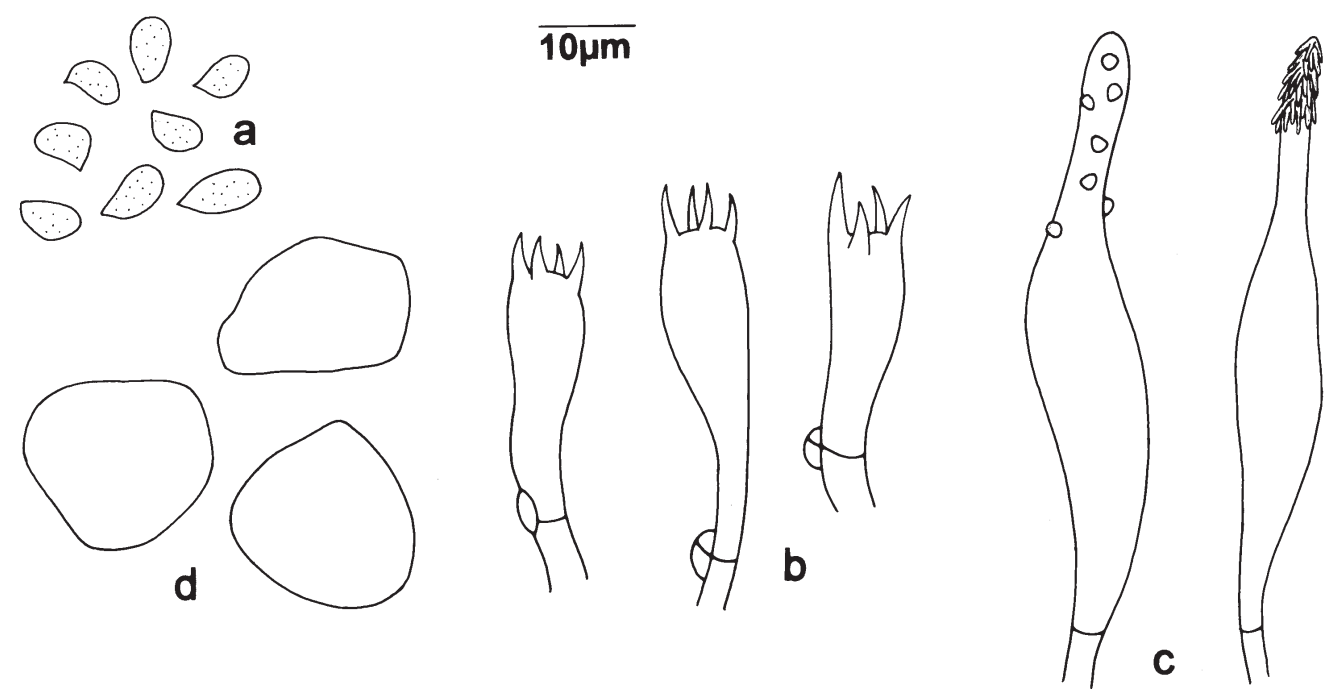

Figure 3. Ripartitella brasiliensis. a. Basidiospores. b. Basidia. c. Pleurocystidia. d. Detersile elements of pilear surface. 
Tanzania, Trinidad, Uganda (Pegler 1977), United States (Ovrebo 1988).

Material examined: BRAZIL. SÃo PaUlo: Santo André, Reserva Biológica de Paranapiacaba, 10-VI1991, L.K. Okino 225 (SP); idem, 10-VI-1991, L.K. Okino 228 (SP); São Paulo, Parque Estadual das Fontes do Ipiranga, in fissure at Seção de Micologia e Liquenologia building, 20-X-1995, R. Maziero s.n. (SP393640); idem, 22-I-1996, L.K. Okino s.n. (SP215009); idem, 15-II-2008, F. Karstedt \& L.A. Ramos 1077 (SP).

Ripartitella brasiliensis is a well characterized species because of the pileus colour covered with minute squamules ranging from brownish to reddish-brown, sinuated lamellae, size and type of pleurocystidia, visible at stereoscopic microscope, and the characteristic minute echinulate basidiospores. The basidiospore ornamentation is very small and is better visualized with Melzer's reagent with immersion oil.

Ripartitella alba Halling \& Franco-Mol., described from Costa Rica is very close to $R$. brasiliensis, differing according to Halling \& FrancoMolano (1996) by the less squamulose to glabrous pileus, less and different pigmentation, smaller habit, wider spacing between lamellae, smaller spores, and smaller cystidia of $R$. alba. It is evident in macroscopic appearance of $R$. alba, according to published photographs of type material (Halling \& Franco-Molano 1996, Halling \& Mueller 2005) that it is quite different from $R$. brasiliensis.

Bandala et al. (2005) mentioned R. alba as occurring in Mexico. But, by the macroscopic illustrations they presented, the pileus "initially covered with a more or less compact (interrupted), brownish-orange or dull brownish-orange, tomentosesquamulose layer breaking after pileus expansion...", and the absence of cheilocystidia (as in R. brasiliensis), it probably represents a collection of $R$. brasiliensis, not $R$. alba [compare also with the photography published by Ovrebo (1988)]. Wartchow et al. (2007) mentioned R. alba for northeast Brazil.

\section{Acknowledgements}

The authors wish to thank Dr. Ricardo Harakava, Instituto Biológico, for DNA sequencing, and Maria Cecília Tomasi, Instituto de Botânica, for inking the drawings. This study was supported by Fundação de Amparo à Pesquisa do Estado de São Paulo (FAPESP 04/04319-2).

\section{Literature cited}

Bandala, V.M., Montoya, L. \& Jarvio, D. 2005. Agarics from coffee plantations in Eastern Mexico: two new records. Fungal Diverstiy 20: 19-29.

Bononi, V.L.R., Trufem, S.F.B. \& Grandi, R.A.P. 1981. Fungos macroscópicos do Parque Estadual das Fontes do Ipiranga, São Paulo, Brasil, depositados no Herbário do Instituto de Botânica. Rickia 9: 37-53.

Capelari, M. 1989. Agaricales do Parque Estadual da Ilha do Cardoso (exceto Tricholomataceae). Dissertação de Mestrado, Universidade de São Paulo, São Paulo.

Dennis, R.W.G.1953. Lepiota and allied genera in Trinidad, Brithish West Indies. Kew Bulletin 7: 459-499.

Dennis, R.W.G. 1961 . Fungi Venezuelani: IV. Agaricales. Kew Bulletin 15: 67-156.

Dennis, R.W.G. 1970. Fungi flora of Venezuela and adjacent countries. Kew Bulletin Additional Series 3: 1-531.

Ferreira, M.E. \& Grattapaglia, D. 1995. Introdução ao uso de marcadores moleculares em análises genéticas. EMBRAPA-CENARGEN, Brasília.

Franco-Molano, A.E. 1993. Studies on Cystoderma: a new species and a new combination. Mycologia 85: 672-676.

Garnica, S., Weiss, M., Walther, G. \& Oberwinkler, F. 2007. Reconstructing the evolution of agarics from nuclear gene sequences and basidiospore ultrastructure. Mycological Research 111: 1019-1029.

Grandi, R.A.P., Guzmán, G. \& Bononi, V.L. 1984. Adições às Agaricales (Basidiomycetes) do Parque Estadual das Fontes do Ipiranga, São Paulo, SP, Brasil. Rickia 11: 27-33.

Guzmán-Dávalos,L. \& Guzmán, G. 1988. Primer registro de Ripartitella brasiliensis (Fungi, Agaricales) en Mexico. Acta Botánica Mexicana 4: 9-13.

Hall, T.A. 1999. BioEdit: a user-friendly biological sequence alignment editor and analysis program for Windows 95/98/NT. Nucleic Acids Symposium Series 41: $95-98$

Halling, R.E. \& Franco-Molano, A.E. 1996. Agaricales from Costa Rica: New taxa with ornamented spores. Mycologia 88: 666-670.

Halling,R.E.\& Mueller, G.M.2005.Common Mushrooms of the Talamanca Mountains, Costa Rica. Memoirs of The New York Botanical Garden 90: 1-195.

Harmaja, H. 1979. Studies in the genus Cystoderma. Karstenia 19: 25-29.

Harmaja, H. 2002. Amylolepiota, Clavicybe and Cystodermella, new genera of the Agaricales. Karstenia 42: 39-48.

Heinemann, P. \& Thoen, D. 1973. Observations sur le genre Cystoderma. Bulletin Trimestriel da la Société Mycologique de France 89: 5-34. 
Johnson, J. \& Vilgalys, R. 1998. Phylogenetic systematics of Lepiota sensu lato based on nuclear large subunit rDNA evidence. Mycologia 90: 971-979.

Kirk, P.M., Cannon, P.F., David, J.C. \& Stalpers, J.A. 2001. Ainsworth \& Bisby's Dictionary of the Fungi. 9th ed. $\mathrm{CAB}$ international, Wallingfor.

Kirk, P.M., Cannon, P.F., Minter, D.W. \& Stalpers, J.A. 2008. insworth \& Bisby's Dictionary of the Fungi. 10th ed. CAB international, Wallingfor.

Küppers, H. 1979. Atlas de los colores. Editorial Blume, Barcelona.

Matheny, P.B., Curtis, J.M., Hofstetter, V., Aime, M.C., Moncalvo, J.-M., Ge, Z.W., Yang, Z.L., Sot, J.C., Ammirati, J., Baroni, T.J., Bougher, N.L., Hughes, K.W., Lodge, D.J., Kerrigan, R.W., Seidl, M.T., Aanen, D.K., DeNitis, M., Daniele, G.M., Desjardin, D.E., Kropp, B.R., Norvell, L.L., Parker, A., Vellinga, E.C., Vilgalys, R. \& Hibbett, D.S. 2006. Major clades of Agaricales: a multilocus phylogenetic overview. Mycologia 98: 982-995.

Meijer, A.A.R. 2001. Mycological work in the Brazilian state of Paraná. Nova Hedwigia 72: 105-159.

Mitchel,D.H.\& Smith,A.H. 1976. Notes on Colorado fungi II. Species of Armillaria (Fr.) Kummer. (Agaricales). Mycotaxon 4: 513-533.

Moncalvo, J.-M., Lutzoni, F.M., Rehner, S.A., Johnson, J. \& Vilgalys, R. 2000. Phylogenetic relationships of agaric fungi based on nuclear large subunit ribosomal DNA sequences. Systematic Biology 49: 278-305.

Moncalvo, J.-M., Vilgalys, R., Redhead, S.A., Johnson, J.E., James, T.Y.,Aime, M.C.,Hofstetter, V., Verduin, S.J.W., Larsson, E., Baroni, T.J., Thorn, R.G., Jacobsson, S., Clémençon, H. \& Miller Jr., O.K. 2002. One hundred and seventeen clades of euagarics. Molecular Phylogenetics and Evolution 23: 357-400.

Ovrebo, C.L. 1988. Notes on the cultural characters, morphology and distribution of Ripartitella brasiliensis. Mycotaxon 31: 229-237.

Pegler,D.N. 1977. A preliminary agaric flora of East Africa. Kew Bulletin Additional Series 7: 1-615.

Pegler, D.N. 1983. The Agaricales of the Lesser Antilles. Kew Bulletin Additional Series 9: 1-668.

Pegler, D.N. 1990. Agaricales of Brazil described by J.P.F.C. Montagne. Kew Bulletin 45: 161-177.
Pegler, D.N. 1997. The Agarics of São Paulo State, Brazil. Royal Botanic Gardens, Kew.

Pouzar, Z. 1957. Nova genera macromycetum I. Česká Mykologie 11: 48-50.

Saar, I. 2003. The genera Cystoderma and Cystodermella (Tricholomataceae) in temperate Eurasia. Mycotaxon 86: 455-473.

Singer, R. 1946. Type studies on Agarics - II. Lloydia 9: 114-131.

Singer, R. 1947. New genera of fungi. III. Mycologia 39: 77-89.

Singer, R. 1949. The "Agaricales" (mushrooms) in modern taxonomy. Lilloa 22: 5-832.

Singer, R. 1969. Mycoflora australis. Beihefte zur Nova Hedwigia 29: 1-405.

Singer, R. 1986. The Agaricales in Modern Taxonomy. 4 ed. Koeltz Scientific Books, Koenigstein.

Smith, A.H. \& Singer, R. 1945. A monograph on the genus Cystoderma. Papers of the Michigan Academy of Science Arts \& Letters 30: 71-124.

Spegazzini, C. 1889. Fungi Puiggariani. Boletin de la Academia Nacional de Ciencias de Cordoba 11: 381622.

Swofford, D. 2001. PAUP* Phylogenetic analysis using parsimony (*and other methods), version $40 \mathrm{~b} 10$. Sinauer Associates, Sunderland.

Thoen, D. 1969. Le genre Cystoderma (Tricholomataceae) en Afrique centrale. Bulletin du Jardin Botanique Naturelle du Belgique 39: 183-190.

Thompson, J.D., Higgins, D.G. \& Gibson, T.J. 1994. Clustal W: improving the sensitivity of progressive multiple sequence alignment through sequence weighting, position-specific gap penalties and weight matrix choice. Nucleic Acids Research 22: 4673 4680.

Vellinga, E.C. 2001. Studies in Lepiota IV - Lepiota cristata and Lepiota castaneidisca. Mycotaxon 80: 297-306.

Walther, G., Garnica,S.\& Weiß, M. 2005. The systematic relevance of conidiogenesis modes in the gilled Agaricales. Mycological Research 109: 525-544.

Wartchow, F., Putzke, J. \& Cavalcanti, M.A.Q. 2007. Ripartitella (Agaricales) from an Atlantic Forest in Pernambuco, Brazil. Mycotaxon 100: 261-268. 